Article

\title{
Composites Based on Nanoparticle and Pan Electrospun Nanofiber Membranes for Air Filtration and Bacterial Removal
}

\author{
Ana Cláudia Canalli Bortolassi ${ }^{1}$, Vádila Giovana Guerra ${ }^{1}$, Mônica Lopes Aguiar ${ }^{1}$, \\ Laurence Soussan $^{2}$, David Cornu ${ }^{2}$ (D) Philippe Miele ${ }^{2}$ (D) and Mikhael Bechelany ${ }^{2, *(D)}$ \\ 1 Departamento de Engenharia Química, Universidade Federal de São Carlos-UFSCar, Rodovia Washington \\ Luiz, km 235-SP 310, São Carlos 13565-905, Brazil; acanallibortola@deakin.edu.au (A.C.C.B.); \\ vadila@ufscar.br (V.G.G.); mlaguiar@ufscar.br (M.L.A.) \\ 2 Institut Européen des Membranes, IEM-UMR 5635, ENSCM, CNRS, Univ Montpellier, 34070 Montpellier, \\ France; laurence.soussan@univ-montp2.fr (L.S.); david.cornu@enscm.fr (D.C.); \\ philippe.miele@umontpellier.fr (P.M.) \\ * Correspondence: mikhael.bechelany@umontpellier.fr; Tel.: +33-0467-149-167
}

Received: 19 November 2019; Accepted: 3 December 2019; Published: 6 December 2019

\begin{abstract}
Often, solid matter is separated from particle-laden flow streams using electrospun filters due to their high specific surface area, good ability to capture aerial particulate matter, and low material costs. Moreover, electrospinning allows incorporating nanoparticles to improve the filter's air filtration efficiency and bacterial removal. Therefore, a new, improved polyacrylonitrile (PAN) nanofibers membrane that could be used to remove air pollutants and also with antibacterial activity was developed. We engineered three different filters that are characterized by the different particles embedded in the PAN nanofibers: titanium dioxide $\left(\mathrm{TiO}_{2}\right)$, zinc oxide $(\mathrm{ZnO})$, and silver $(\mathrm{Ag})$. Then, their filtration performance was assessed by quantifying the filtration of sodium chloride $(\mathrm{NaCl})$ aerosol particles of 9 to $300 \mathrm{~nm}$ in diameter using a scanning mobility particle sizer. $\mathrm{The}^{\mathrm{TiO}}{ }_{2} \mathrm{~F}$ filter displayed the smallest fiber diameter and the highest filtration efficiency $(\approx 100 \%)$. Conversely, the Ag_F filter showed the highest quality factor $\left(\approx 0.06 \mathrm{~Pa}^{-1}\right)$ because of the lower air pressure drop. The resulting Ag_F nanofibers displayed a very good antibacterial activity using an Escherichia coli suspension $\left(10^{8} \mathrm{CFU} / \mathrm{mL}\right)$. Moreover, the quality factor of these membranes was higher than that of the commercially available nanofiber membrane for air filtration.
\end{abstract}

Keywords: air filtration; nanoparticles; electrospinning

\section{Introduction}

Fossil fuels and industries release many pollutants in the atmosphere [1]. Particles smaller than $2.5 \mu \mathrm{m}\left(\mathrm{PM}_{2.5}\right)$ are particularly dangerous for humans because their small size facilitates their diffusion in bronchi and lungs [2]. The particulate matter's size is determined by how such particles are produced. For example, the size of combustion particles is normally about $10-50 \mathrm{~nm}$; however, they can combine with other particles and generate larger particulates. All these agglomerated particles can be released in the air when broken down. Complex mixtures of particles, most of them usually with a diameter smaller than $1000 \mu \mathrm{m}$, are the contaminants that are eliminated by air filtration. The diameter of particles in chemical and biological aerosols varies between 1 and $10 \mu \mathrm{m}$ (particles smaller than $2.5 \mu \mathrm{m}$ are particularly dangerous for human health).

Therefore, industries that need to produce material with the lowest possible amount of impurities are very interested in filters that can trap particulate and biological contaminants. Indeed, the size of the industrial air-filtration market should exceed USD 6.5 billion by 2024 [3]. However, the existing 
high-efficiency air filters cannot block particles smaller than $3 \mu \mathrm{m}$ in diameter or small pathogenic agents, such as viruses that are smaller than $1 \mu \mathrm{m}$ [4]. Particles of diameter smaller than a unit density sphere take more time to settle in air compared with bigger particles [5]. Therefore, advanced filtration technologies are needed to capture such nanometric particles. Moreover, heating, ventilating, and air conditioning air filters that are designed to purify air in wet, dark, and ambient temperature conditions are more likely to be colonized by bacteria, molds, and fungi. This leads to bad odor and poor air quality [6]. Therefore, new filters need to be developed or existing filters need to be improved due to the increased resistance of microorganisms and also the limits of their antimicrobial activity [4].

Currently, membrane filtration is thought to be the most effective physical approach against air pollutants [7]. Nanofiber membranes can trap most contaminants and can qualify as high-efficiency particulate air (HEPA) filters. Moreover, they are characterized by low air pressure drop and basis weight as well as compact structure. The filter efficiency in separating particles from the air stream is influenced by the particle composition, shape, filtration velocity, and type of impaction surface [8]. Membrane filters rely on physical interactions to efficiently separate and collect particles. Data from many different studies led to the general conclusion that filtration efficiency increases with high basis weight and decreases with higher superficial flow velocity [9-11].

Therefore, novel fibrous filters with lower energy consumption for air purification require the development of resistant fibers with high filtration efficiency and low pressure drop [12]. Electrospinning is a highly popular method to produce many different fiber morphologies including very fine diameters, various porosities and pore sizes (from nanometers to micrometers), and great mechanical strength, thanks to inter-fiber connections [13-17]. A surface modification can enhance electrospun nanofibers when nanoparticles are incorporated in membranes.

Some studies have already investigated the addition of active nanoscale materials, such as $\mathrm{SiO}_{2}$, $\mathrm{Al}_{2} \mathrm{O}_{3}$, and $\mathrm{CuO}$, in electrospun fibers to improve their air pollutant filtration capacity and also increase their mechanical, thermal, and chemical resistance [18-20]. Several groups have focused on titanium dioxide $\left(\mathrm{TiO}_{2}\right)$ and zinc oxide $(\mathrm{ZnO})$ due to their potential as antibacterial agents, mainly linked to their small particle size, high surface area, photocatalytic bactericidal activity, self-cleaning properties, and low cost [21,22]. After their adsorption to the bacterial cell surface, $\mathrm{Zn}$ and Ti ions cross the cell membrane and cause cell disruption, DNA damage, protein activity inhibition, and ultimately cell death [23-25]. Silver (Ag) nanoparticles and salts also display particularly attractive antimicrobial effects. Indeed, they are non-toxic to human cells but are highly effective against bacteria, fungi, and viruses [26]. In addition, Ag nanoparticles' bactericidal properties against a wide range of microorganisms are mediated through the production of reactive oxygen species [27]. However, the aggregation and dissolution of $\mathrm{Ag}, \mathrm{TiO}_{2}$, and $\mathrm{ZnO}$ nanoparticles are still a challenge for practical application [28].

Polyacrylonitrile (PAN) has been widely used for the production of membranes because it displays a very good mechanical strength and chemical stability [29]. Several studies have investigated nanofibers made of polymers and bactericidal particles to be used as air filters [30-32]. Moreover, $\mathrm{Ag}$, $\mathrm{TiO}_{2}$, and $\mathrm{ZnO}$ antimicrobial activity has been widely studied [33-36]. However, to our knowledge, no study has concomitantly analyzed their bactericidal effect and ability to trap $\mathrm{NaCl}$ particles smaller than $300 \mathrm{~nm}$. Sim et al. [37] showed a high antimicrobial activity (>99\%), filtration efficiency ( $92.5 \%$ against a $300 \mathrm{~nm}$ $\mathrm{KCl}$ aerosol), and small pressure drop $(\sim 0.8 \mathrm{mmAq}$ at $13 \mathrm{~cm} / \mathrm{s})$ of an antimicrobial-nanoparticle-coated electrostatic air filter in an indoor environment. Lv et al. [38] analyzed the performance of nanofiber membranes composed of poly(vinyl alcohol) (PVA) and konjac glucomannan (KGM), and loaded with $\mathrm{ZnO}$ nanoparticles for air filtration and water treatment. These nanofiber membrane filters showed an efficient air-filtration performance ( $>99.9 \%$ for ultrafine particles, $300 \mathrm{~nm}$ ), excellent photocatalytic activity, and antibacterial activity against Gram-negative (Escherichia coli) and Gram-positive bacteria (Bacillus subtilis). Recently, we described novel electrospun Ag/PAN fibers that could be used as air filters for nanoparticle removal, and that showed antibacterial activity [39]. 
Here, we used electrospinning to fabricate novel PAN membranes loaded with active $\mathrm{ZnO}, \mathrm{TiO}_{2}$, or Ag nanoparticles to increase their air-filtration efficiency, lower the pressure drop, and improve their quality factor, and exhibit bactericidal activity. Moreover, we analyzed the fiber distribution to understand its influence on the filtration of sub-300-nm particles.

\section{Materials and Methods}

\subsection{Materials}

PAN ( $\mathrm{M}_{\mathrm{w}} \sim 150,000 \mathrm{~g} / \mathrm{gmol}$; CAS Number 25014-41-9), N,N-dimethylformamide (DMF; 99.8\%; CAS number 68-12-2), $\mathrm{TiO}_{2}\left(\mathrm{M}_{\mathrm{w}} \sim 79,87 \mathrm{~g} / \mathrm{gmol}\right.$; CAS number 13463-67-7), $\mathrm{ZnO}\left(\mathrm{M}_{\mathrm{w}} \sim 81,39 \mathrm{~g} / \mathrm{gmol}\right.$; CAS number 1314-13-2), and silver nitrate $\left(\mathrm{AgNO}_{3} ; \mathrm{M}_{\mathrm{W}} \sim 169.87 \mathrm{~g} / \mathrm{gmol}\right.$; $\mathrm{CAS}$ number 7761-88-8) were bought from Sigma Aldrich (St. Louis, MO, USA). The substrate made of polyethylene terephthalate (PET) fibers and used to collect nanofibers was from Freudenberg (Weinheim, Baden-Württemberg, GE). $\mathrm{NaCl}$ (99\%; CAS number 7647-14-5) was from Sigma Aldrich (St. Louis, MO, USA) and was used to produce nanoparticles to determine the membrane's filter-removal efficiency.

\subsection{Methods}

\subsubsection{Preparation of $\mathrm{TiO}_{2} / \mathrm{PAN} / \mathrm{DMF}, \mathrm{ZnO} / \mathrm{PAN} / \mathrm{DMF}$, and Ag/PAN/DMF Solutions}

Nanofibers were produced by dissolving $0.95 \mathrm{~g}$ of PAN polymer $(9.1 \mathrm{wt} \%)$ in $10 \mathrm{~mL}$ of DMF. After $2 \mathrm{~h}$ of agitation, $0.95 \mathrm{~g}$ of $\mathrm{TiO}_{2}, \mathrm{ZnO}$, or $\mathrm{AgNO}_{3}$ (the same amount as for PAN) were added in the PAN solution. The average size of the obtained $\mathrm{TiO}_{2}, \mathrm{ZnO}$, and $\mathrm{Ag}$ nanoparticles was 21, 50, and $5 \mathrm{~nm}$, respectively, according to the supplier. Solutions were continuously stirred in the dark and at room temperature for $48 \mathrm{~h}$ to form a homogenous solution. This period of time was necessary to allow $\mathrm{AgNO}_{3}$ reduction to $\mathrm{Ag}$ nanoparticles using DMF as solvent at room temperature and without any reducing agent [40-42]. Ag nanoparticles changed color due to the surface plasmon resonance (SPR) phenomenon that occurs when light is reflected off a thin metal film or nanoparticles [36]. Conversely, the $\mathrm{ZnO} / \mathrm{PAN} / \mathrm{DMF}$ and $\mathrm{TiO}_{2} / \mathrm{PAN} / \mathrm{DMF}$ solutions did not change color after stirring for $48 \mathrm{~h}$. Viscosity was measured with a Brookfield viscometer spindle 29 (TC-650, AMETEK Brookfield, Middleborough, MA, USA) and conductivity with an electrical conductivity meter (TEC-4MP, Tecnal, Piracicaba, San Paulo, Brazil).

\subsubsection{Fabrication of $\mathrm{TiO}_{2} / \mathrm{ZnO} / \mathrm{Ag}$-PAN Nanofibers by Electrospinning}

The different nanoparticle/PAN/DMF solutions were loaded in $12 \mathrm{~mL}$ syringes with $0.7 \mathrm{~mm}$ diameter needles and were fed (flow rate $=0.2 \mathrm{~mL} / \mathrm{h}$ ) into the home-made electrospinning system using a syringe pump (KDS 100, KD Scientific, Holliston, MA, USA) [43-45] powered (25 kV) by a High Voltage Power Supply (T1CP 300 304n-iSeg, Radeberg, Germany). Nanofibers were deposited on PET films (i.e., the substrate) wrapped around the rotating machine. The syringe tip-collector distance was set at $15 \mathrm{~cm}$. The prepared filter media were named $\mathrm{Ag}_{-} \mathrm{F}, \mathrm{TiO}_{2} \_\mathrm{F}, \mathrm{ZnO} \_\mathrm{F}$, and PAN_F when $\mathrm{AgNO}_{3}$, $\mathrm{TiO}_{2}, \mathrm{ZnO}$, and no nanoparticles were added to the PAN solution, respectively. During electrospinning, the high applied voltage was obtained by connecting the positive and ground terminals to the nozzle and collector, respectively. When the jet exceeded a critical voltage, a stable jet of liquid was ejected from the syringe tip. After solvent evaporation, nanofibers were produced and deposited on the collector surface where the non-woven substrate was placed. This process was carried out at approximately $20^{\circ} \mathrm{C}$ under atmospheric air and the substrate was on a grounded metal roller $(10 \mathrm{~cm}$ in diameter) that rotated at $300 \mathrm{rpm}$ for $1 \mathrm{~h}$ for each experiment.

\subsubsection{Structural and Morphological Analysis of Nanofiber Filters}

Energy-dispersive X-ray (EDX) spectroscopy and elemental mapping were performed using a Zeiss EVO HD15 microscope (Oberkochen, Germany) coupled to an Oxford X-MaxN EDX detector 
(Oxford Instruments, Abingdon, UK) to measure the atomic percentage (Figure S1). The nanofiber diameter distribution was analyzed by scanning electron microscopy (SEM) with a Hitachi S4800 microscope (Tokyo, Japan), and thickness was measured with a caliper (Starrett, Athol, MA, USA). The fiber diameter was measured from SEM images using Image J1.29X as described by Bortolassi et al. [46]. The fiber size distribution was determined by measuring 100 fibers of each filter medium.

An attractive air filter should display low pressure drop and high permeability. Permeability was assessed by varying the air velocity from 0.3 to $3 \mathrm{~cm} / \mathrm{s}$, and pressure drop $(\Delta P)$ was quantified with a digital manometer (VelociCalc Model 3A-181WP09, TSI, Shoreview, MN, USA) linked to the filtration apparatus, as previously described [46].

As the filtration velocity used in this study was low, the permeability constant $\left(k_{1}\right)$ was calculated using Darcy's law that analyzes the fluid flow of the filter media relative to the pressure drop $(\Delta P)$, thickness $(L)$, air viscosity $(\mu)$, and superficial velocity $\left(v_{s}\right)$ :

$$
\frac{\Delta P}{L}=\frac{\mu}{k_{1}} v_{s}
$$

The pore-size distributions of the webs was assessed with a capillary flow porometer ( 3 gzh Quantachrome, Anton Paar, Graz, Austria), as previously described [47]. The pore distribution, mean pore size, and bubble point were measured at pressure values ranging from 0.3 to 0.8 bar and using isopropanol as wetting liquid. The pore size-pressure relationship is described by Equation (2):

$$
P=\frac{4 \gamma_{l / g} \operatorname{Cos} \theta}{d}
$$

where, $P$ is the applied pressure, $\gamma_{l / g}$ is the wetting liquid surface tension, $\theta$ is the wetting angle, and $d$ is the pore diameter.

\subsubsection{Testing the Nanofiber Filter's Filtration Performance}

Nanoparticles of different sizes (from 9 to $300 \mathrm{~nm}$ ) were generated using $0.1 \mathrm{~g} / \mathrm{L}$ of $\mathrm{NaCl}$ solution and an atomizer aerosol generator to obtain the same, standard particle size distribution curve for all tested filters.

The experimental unit included an air compressor (Shultz, Acworth, GA, USA), air purification filters (Model A917A-8104N-000 and 0A0-000), an atomizer aerosol generator (Model 3079, TSI, Shoreview, MN, USA), a diffusion dryer (Norgren IMI, Birmingham, UK), a Kriptônio and Americium neutralizing source (Model 3054, TSI, Shoreview, MN, USA), a filter apparatus, a flowmeter tube size 3 (Gilmont, Vernon Hills, IL, USA), and a scanning mobility particle sizer that comprises an electrostatic classifier (Model 3080, TSI, Shoreview, MN, USA), a differential mobility analyzer, and an ultrafine particle counter (Model 3776, TSI, Shoreview, MN, USA), as described by Bortolassi et al. [46].

The nanoparticle concentration upstream $\left(C_{u p}\right)$ and downstream $\left(C_{d}\right)$ of the filter medium was calculated using the differential mobility analyzer and particle counter and the following equation:

$$
n_{t}=\frac{C_{u p}-C_{d}}{C_{u p}}
$$

Filtration efficiency was tested at constant superficial velocity $(0.05 \mathrm{~m} / \mathrm{s})$, flow rate $(1.50 \mathrm{~L} / \mathrm{min})$, and filtration area $\left(5.3 \mathrm{~cm}^{2}\right)$. Experiments were repeated three times and data were presented as the mean \pm standard deviation. The experimental and theoretical collection efficiency of the filter media were compared with Equation (4) [48]:

$$
n_{t}=n_{d}+n_{i}+n_{i d}+n_{g}+n_{e}
$$


where $n_{t}$ is the total collection efficiency, $n_{d}$ is the diffusion, $n_{i}$ the inertial, $n_{i d}$ the interception, $n_{g}$ the gravitational, and $n_{e}$ the electrophoretic mechanism. For our test, diffusion, inertial, and interception are the most important mechanisms and are influenced by different parameters, particularly air velocity, fiber and particle diameter, and porosity.

Quality factor $\left(Q_{F}\right)$ also is used to describe the effectiveness of filter media. It was assessed by relating the pressure drop to the removal efficiency of 100-nm particles, as described by Equation (5) [48]:

$$
Q_{F}=\frac{-\ln (1-n)}{\Delta P}
$$

where $\Delta P$ is the pressure drop across the filter and $n$ is the removal efficiency.

The minimum efficiency at the most penetrating particle size typically ranges from $0.1 \mu \mathrm{m}$ and $0.5 \mathrm{~mm}$, and is influenced to various degrees by different mechanical mechanisms (e.g., interception, diffusion, and inertial impaction) involved in particle filtration [49]. Moreover, it is generally acknowledged that particles from an aerosol will be removed more efficiently by a thick filter, but with higher pressure drops. Conversely, removal by a thin, open-porous filter is usually less efficient, but this filter type is more permeable. Therefore, further increasing the filter efficiency could compensate for the higher pressure drop. Hence, high $Q_{F}$ values are the result of a balance between efficiency and pressure drop.

\subsubsection{Bactericidal Activity}

Antibacterial tests were performed using non-pathogenic Gram-negative E. coli bacteria (K12 DSM 423, from DSMZ, Braunschweig, Germany). Lysogeny broth (LB) Miller was used for E. coli culture, counting, and direct-contact agar tests. For each experiment, a new bacterial suspension was prepared from frozen E. coli aliquots kept at $-20^{\circ} \mathrm{C}$. After rehydration in LB medium at $30{ }^{\circ} \mathrm{C}$ on a rotating shaker $(160 \mathrm{rpm})$ for $3 \mathrm{~h}$, aliquots were inoculated in fresh LB medium $(5 \% \mathrm{v} / \mathrm{v})$ and incubated at $30{ }^{\circ} \mathrm{C}$ under constant stirring $(160 \mathrm{rpm})$ overnight to reach the stationary growth phase. Then, bacteria were centrifuged (4000 $\mathrm{rpm}$ and $12{ }^{\circ} \mathrm{C}$ for $10 \mathrm{~min}$ ) and supernatants were discarded to remove nutrients. Bacterial pellets were suspended in spring water (Cristaline Sainte Cécile, Sainte-Cécile, France: $\left[\mathrm{Ca}^{2+}\right]=39 \mathrm{mg} / \mathrm{L},\left[\mathrm{Mg}^{2+}\right]=25 \mathrm{mg} / \mathrm{L},\left[\mathrm{Na}^{+}\right]=19 \mathrm{mg} / \mathrm{L},\left[\mathrm{K}^{+}\right]=1.5 \mathrm{mg} / \mathrm{L},\left[\mathrm{F}^{-}\right]<0.3 \mathrm{mg} / \mathrm{L}$, $\left.\left[\mathrm{HCO}_{3}{ }^{-}\right]=290 \mathrm{mg} / \mathrm{L},\left[\mathrm{SO}_{4}{ }^{2-}\right]=5 \mathrm{mg} / \mathrm{L},\left[\mathrm{Cl}^{-}\right]=4 \mathrm{mg} / \mathrm{L},\left[\mathrm{NO}_{3}{ }^{-}\right]<2 \mathrm{mg} / \mathrm{L}\right)$ to block bacterial growth. The bacterial concentration in the suspension was measured by absorbance measurements at $600 \mathrm{~nm}$ and adjusted according to a calibration curve previously prepared in the laboratory. The suspension was diluted with spring water to $10^{8}$ and $10^{3} \mathrm{CFU} / \mathrm{mL}$. To test the antibacterial activity of $\mathrm{ZnO} / \mathrm{TiO} / \mathrm{Ag}-\mathrm{PAN}$ materials, direct-contact agar tests were done using nutritive LB agar plates. Briefly, $40 \mu \mathrm{L}$ of bacterial suspension was deposited on sterile $2.25 \mathrm{~cm}^{2}\left(\mathrm{Ag} \_\mathrm{F}, \mathrm{TiO}_{2}\right.$ F, $\mathrm{ZnO}$ _F , and PAN_F) samples that were previously sterilized by UV exposure for $30 \mathrm{~min}$. The inoculated side of the samples was placed on nutritive LB agar at room temperature for $6 \mathrm{~h}$ and then removed. Then, plates were incubated at $30{ }^{\circ} \mathrm{C}$ overnight to allow the growth of bacterial colonies (each bacterium should produce one colony). The bacterial log removal could also be calculated for the lowest bacterial concentration tested (i.e., $10^{3} \mathrm{CFU} / \mathrm{mL}$ ). In the positive controls, the bacterial suspension was placed directly on LB agar plates without pre-incubation with any sample. Each test was performed in triplicate.

\section{Results and Discussion}

Electrospinning was used to fabricate PAN nanofiber filters (PAN_F) that included different bactericidal nanoparticles $\left(\mathrm{Ag}, \mathrm{TiO}_{2}\right.$, or $\left.\mathrm{ZnO}\right)$. After nanoparticle addition (0.95 g of $\mathrm{AgNO}_{3}, \mathrm{TiO}_{2}$, or $\mathrm{ZnO})$ in the PAN solution $(9.1 \mathrm{wt} \%)$, viscosity and conductivity were analyzed. The obtained filter media were named $\mathrm{Ag}_{-} \mathrm{F}, \mathrm{TiO}_{2} \_\mathrm{F}$, and $\mathrm{ZnO} \_\mathrm{F}$, respectively. Then, the different features of PAN nanofibers and $\mathrm{Ag} / \mathrm{TiO}_{2} / \mathrm{ZnO}-\mathrm{PAN}$ nanofibers were analyzed (fiber distribution, thickness, porosity, permeability, and pressure drop) as well as their filtration performance, $Q_{F}$, and bactericidal activity. 


\subsection{Solution Characterization}

Quantification of conductivity and viscosity (Table 1 ) showed that after adding $\mathrm{AgNO}_{3}$ to the PAN solution, Ag nanoparticles were formed (confirmed by Bortolassi et al. [39]), and conductivity changed. Moreover, viscosity increase was much higher in the $\mathrm{Ag}_{-} \mathrm{F}$ solution than in the $\mathrm{TiO}_{2} \mathrm{~F}$ and $\mathrm{ZnO} \_\mathrm{F}$ solutions. A very high viscosity could affect nanofiber deposition, as a result of the hard ejection of jets from the solution, as proposed by Li \& Wang [50]. Therefore, the higher Ag_F conductivity and viscosity led to the deposition of thinner and lighter fiber layers compared with the other solutions. Moreover, high viscosity could hinder the formation of electrospun nanofibers.

Table 1. Conductivity and viscosity measured at $25^{\circ} \mathrm{C}$.

\begin{tabular}{ccc}
\hline Solutions & Conductivity $(\mathrm{mS} / \mathrm{cm})$ & Viscosity $(\mathbf{c P})$ \\
\hline $\mathrm{PAN} / \mathrm{DMF}$ & $0.09 \pm 0.01$ & $471 \pm 0$ \\
$\mathrm{Ag} / \mathrm{PAN} / \mathrm{DMF}$ & $2.11 \pm 0.05$ & $933 \pm 1$ \\
$\mathrm{TiO}_{2} / \mathrm{PAN} / \mathrm{DMF}$ & $0.09 \pm 0.01$ & $452 \pm 1$ \\
$\mathrm{ZnO} / \mathrm{PAN} / \mathrm{DMF}$ & $0.08 \pm 0.01$ & $567 \pm 1$ \\
\hline
\end{tabular}

\subsection{Structural and Morphological Properties}

SEM imaging and size distribution analysis of $\mathrm{Ag} / \mathrm{TiO}_{2} / \mathrm{ZnO}-\mathrm{PAN}$ nanofibers after electrospinning (Figure 1) showed that PAN_F, Ag_F, and $\mathrm{ZnO}$ _F filters were composed of nanofibers with a mean diameter of $290 \mathrm{~nm}$. $\mathrm{TiO}_{2} \_\mathrm{F}$ filters had the smallest fiber diameter $(242 \mathrm{~nm})$. The substrate used to support the nanofiber deposition was composed of PET microfibers with a mean fiber diameter of approximately $27 \mu \mathrm{m}$.

All filters fabricated in this study were composed of heterogeneous nanofibers, but only $\mathrm{TiO}_{2}$ filters included large nanoparticle agglomerations in the fibers. This could be explained by the large specific surface area and the interaction between $\mathrm{TiO}_{2}$ nanoparticles and $\mathrm{PAN}$ fibers. Indeed, $\mathrm{TiO}_{2}$ nanoparticle aggregation in the middle of fibers could have been favored by electrostatic repulsion of positively charged $\mathrm{TiO}_{2}$ by the positive charges on the fiber surface [51]. Wang et al. [52] also described the agglomeration of $\mathrm{TiO}_{2}$ nanoparticles upon production of PLA $(7 \mathrm{wt} \%)$ fibers with lower concentration of $\mathrm{TiO}_{2}$ nanoparticles $(0.5,1,1.5,1.75$, and $2 \mathrm{wt} \%)$ due to the lower nanopore volume. Lv et al. [33] dissolved $1 \mathrm{~g}$ of KGM and $\mathrm{ZnO}$ nanoparticles (0, 0.5, 1.0, 1.5, and $2.0 \mathrm{wt} \%)$ in PVA solution $(10 \%)$ using ultrasonic stirring, and did not observe any agglomeration. Moreover, it has been reported that in $\mathrm{PAN} / \mathrm{TiO}_{2}$ fibers, $\mathrm{TiO}_{2}$ nanospheres tend to agglomerate more readily due to their smaller sizes compared with $\mathrm{ZnO}$ nanoparticles [51]. Conversely, no cluster was observed upon Ag_F production, probably because Ag nanoparticles can easily spread along nanofibers due to their small size $(5 \mathrm{~nm})$.

As the morphology of electrospun nanofibers can be influenced by many factors, particularly the solution concentration, applied voltage, solution velocity, distance between syringe tip and collector distance, and solution properties (polarity, surface tension, electric conductivity), the same electrospinning conditions were used for all samples in our study. Agglomeration is also influenced by the electrospinning parameters, but this issue was not investigated in this study. 

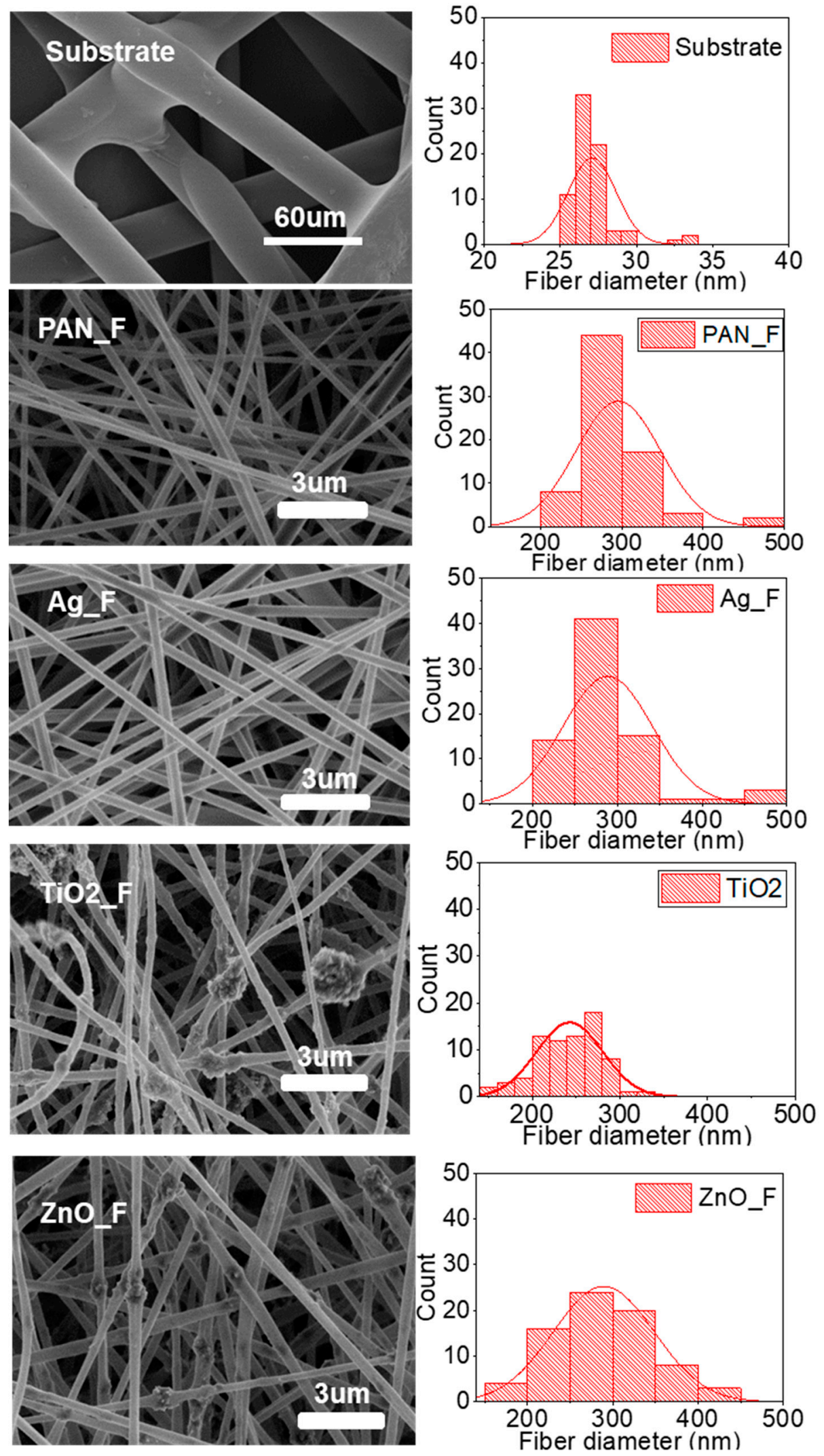

Figure 1. SEM images and fiber diameter distribution for the polyethylene terephthalate (PET) substrate and electrospun polyacrylonitrile nanofiber filter (PAN_F), Ag_F, $\mathrm{TiO}_{2}$ F, and $\mathrm{ZnO}$ _F samples. The red lines show the approximate distribution based on a Gaussian distribution. 
Measurement of the filter's thickness (Table 2) did not highlight any significant difference after the deposition of the electrospun nanofibers on the substrate (S), because the nanofiber layer was very thin. Sample weighing after electrospinning indicated that the basis weight increase was higher in the $\mathrm{TiO}_{2} \_\mathrm{F}$ and $\mathrm{ZnO} \_\mathrm{F}$ than Ag_F samples, probably due to nanoparticle agglomeration. Moreover, the fiber diameter decreased when nanoparticles were added to the PAN solution, as observed by Abdo et al. [53]. The reduced diameter decrease [54] and lower basis weight [50] of the electrospun Ag_F samples can be explained by the higher viscosity and conductivity of the Ag/PAN/DMF solution.

Table 2. Characterization of the electrospun fibrous filters and unwoven substrate.

\begin{tabular}{cccccc}
\hline Samples & PAN (g) & $\begin{array}{c}\text { Nanoparticles } \\
\mathbf{( g )}\end{array}$ & $\begin{array}{c}\text { Mean Fiber } \\
\text { Diameter }(\mathbf{n m})\end{array}$ & $\begin{array}{c}\text { Thickness } \\
\mathbf{( m m})\end{array}$ & $\begin{array}{c}\text { Basis Weight } \\
\mathbf{( g / \mathbf { m } ^ { 2 } )}\end{array}$ \\
\hline PAN_F & 0.95 & - & $301 \pm 7$ & $0.20 \pm 0.01$ & $75 \pm 3$ \\
Ag_F & 0.95 & 0.95 & $292 \pm 6$ & $0.17 \pm 0.01$ & $62 \pm 4$ \\
$\mathrm{TiO}_{2}$ _F & 0.95 & 0.95 & $242 \pm 5$ & $0.19 \pm 0.01$ & $79 \pm 3$ \\
ZnO_F & 0.95 & 0.95 & $289 \pm 5$ & $0.18 \pm 0.01$ & $80 \pm 3$ \\
S & 0 & 0 & $27 \pm 0$ & $0.16 \pm 0.01$ & $61 \pm 1$ \\
\hline
\end{tabular}

The EDX analysis allowed calculating the atomic percentages of $\mathrm{Ag} / \mathrm{Ti} / \mathrm{Zn}$ in the fabricated fibers (Table S1). The obtained values are in agreement with the nanoparticle addition to the PAN solution. Moreover, the atomic percentages of $\mathrm{Ag}, \mathrm{TiO}_{2}$, and $\mathrm{ZnO}$ in the obtained filters were much lower than the percentages introduced in the solutions $\mathrm{Ag} / \mathrm{PAN} / \mathrm{DMF}, \mathrm{TiO}_{2} / \mathrm{PAN} / \mathrm{DMF}$, and $\mathrm{ZnO} / \mathrm{PAN} / \mathrm{DMF}$, respectively. This finding could be explained by the much higher contribution of the substrate (made of PET fibers) to the elemental composition measured by EDX than the thin film of PAN/nanoparticle nanofibers deposited by electrospinning.

Elemental mapping images of $\mathrm{Ag}_{-} \mathrm{F}, \mathrm{TiO}_{2} \mathrm{~F}$, and $\mathrm{ZnO}_{-} \mathrm{F}$ filters (Figure S1) showed that nanoparticles were distributed on the whole area of the analyzed samples, indicating their good dispersion in PAN nanofibers. Altogether, these data demonstrate that electrospinning allowed the successful fabrication of $\mathrm{Ag} / \mathrm{TiO}_{2} / \mathrm{ZnO}$ nanofibers and their deposition on the PET substrate to produce air filters.

Pore size and thickness measurements (Figure 2) showed differences in pore size distribution among samples. The narrowest pore size distribution was observed in Ag_F (1.11-1.16 $\mu$ m; mean value: $1.12 \mu \mathrm{m})$ (Table 3) and the largest in $\mathrm{ZnO} \_\mathrm{F}(1.99-2.17 \mu \mathrm{m}$; mean value: $2.03 \mu \mathrm{m})$. Large pore size is correlated with lower pressure drop because the air can easily go through a filter with wide pores. However, in our experimental set up, pressure drop was more influenced by the filter thickness. The lowest pressure drop was observed with $\mathrm{ZnO}$ _F and Ag_F filters (Figure 3) that displayed the lowest thickness. As mentioned before, the Ag solution's viscosity favored the lower fiber deposition compared with the other filters, as previously reported by $\mathrm{Li}$ and Wang [50]. $\mathrm{TiO}_{2}$ F displayed the highest thickness and also the largest pressure drop. This big pressure drop might be explained by the higher amount of nanofibers deposited on the substrate (facilitated by the low $\mathrm{TiO}_{2}$ solution viscosity) and nanoparticle agglomeration during electrospinning that hindered the air flow through the filter. Finally, the used substrate (S) did not significantly affect the air flow through the filter because the pressure drop was almost zero and the mean pore size of the substrate was $72.74 \mu \mathrm{m}$. Therefore, the substrate did not interfere with the filter performance. On the other hand, the pressure drop increased when PAN_F were deposited on the substrate by electrospinning, probably because increasing the nanofiber layers decreases the void space, hindering air flow through the filter. Conversely, addition of $\mathrm{ZnO}$ and $\mathrm{Ag}$ nanoparticles to the solution resulted in filters with lower pressure drop due to the higher solution viscosity and the consequent lower nanofiber thickness. 


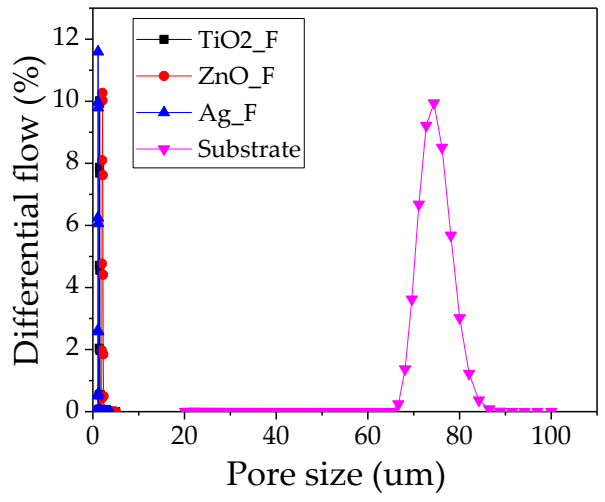

(a)

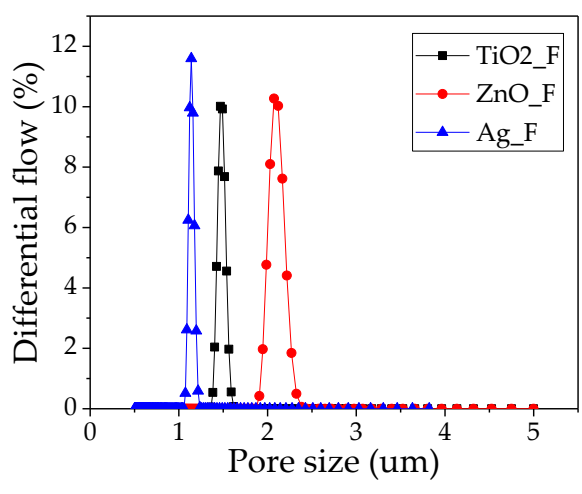

(b)

Figure 2. Pore size distribution: (a) scale $0-100 \mu \mathrm{m}$ and (b) scale $0-5 \mu \mathrm{m}$.

Table 3. Pressure drop and pore size of the electrospun filters.

\begin{tabular}{ccccc}
\hline \multirow{2}{*}{ Samples } & \multirow{2}{*}{$\mathbf{P}$ at $\mathbf{0 . 0 3} \mathbf{~ m / s ~ ( P a )}$} & \multicolumn{3}{c}{ Pore Size $(\boldsymbol{\mu m})$} \\
\cline { 3 - 5 } & & Minimum & Mean & Maximum \\
\hline PAN_F & $174.50 \pm 0.25$ & $1.97 \pm 0.10$ & $2.35 \pm 0.10$ & $2.93 \pm 0.10$ \\
$\mathrm{Ag}$ _F & $68.13 \pm 0.18$ & $1.11 \pm 0.10$ & $1.12 \pm 0.10$ & $1.16 \pm 0.10$ \\
$\mathrm{TiO}_{2}$ F & $183.47 \pm 0.03$ & $1.42 \pm 0.10$ & $1.45 \pm 0.10$ & $1.51 \pm 0.10$ \\
ZnO_F & $81.17 \pm 0.07$ & $1.99 \pm 0.10$ & $2.03 \pm 0.10$ & $2.17 \pm 0.10$ \\
Substrate & $0.60 \pm 0.00$ & $69.59 \pm 0.10$ & $72.74 \pm 0.10$ & $80.04 \pm 0.10$ \\
\hline
\end{tabular}

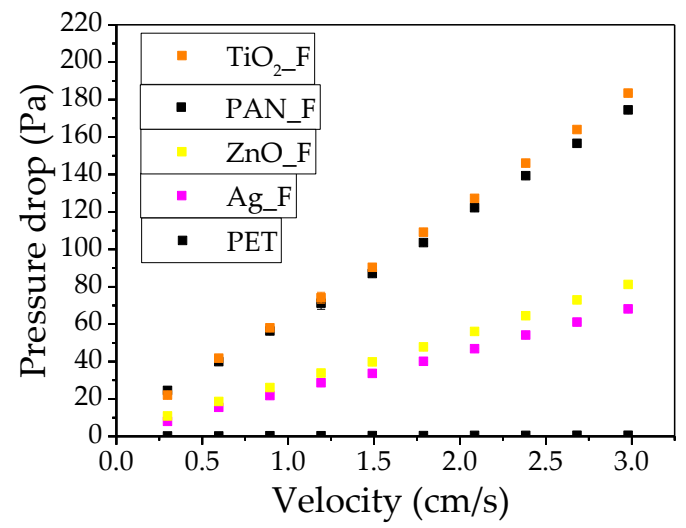

Figure 3. Pressure drop as a function of superficial velocity of electrospun filters.

Finally, Ag_F displayed the highest permeability constant $\left(1.83 \mathrm{E}^{-12} \cdot \mathrm{m}^{2}\right)$ compared with the other filters (Table 4). As permeability is directly proportional to the flow rate, air passed through the Ag_F filter more easily and pressure drop across the filter was reduced (68.13 Pa). This result suggests that adding nanoparticles in the PAN solution beyond a critical value of viscosity hinders the flow of the solution through the needle tip, decreasing the nanofiber deposition and the pressure drop [55-57].

Table 4. Permeability constant of the electrospun filters.

\begin{tabular}{cc}
\hline Samples & $\mathbf{K}_{\mathbf{1}}\left(\mathbf{m}^{\mathbf{2}}\right)$ \\
\hline PAN_F & $6.11 \times 10^{-13}$ \\
Ag_F & $1.83 \times 10^{-12}$ \\
TiÖ_F $_{\text {ZnO_F }}$ & $6.11 \times 10^{-13}$ \\
Substrate & $9.17 \times 10^{-13}$ \\
\hline
\end{tabular}




\subsection{Comparison of the Filtration Performance}

$\mathrm{NaCl}$ nanoparticle with the same size distribution curves (range: 9 to $300 \mathrm{~nm}$ ) were prepared, to test the different filters, using $0.1 \mathrm{~g} / \mathrm{L} \mathrm{NaCl}$ solution and an atomizer aerosol generator (Figure 4).

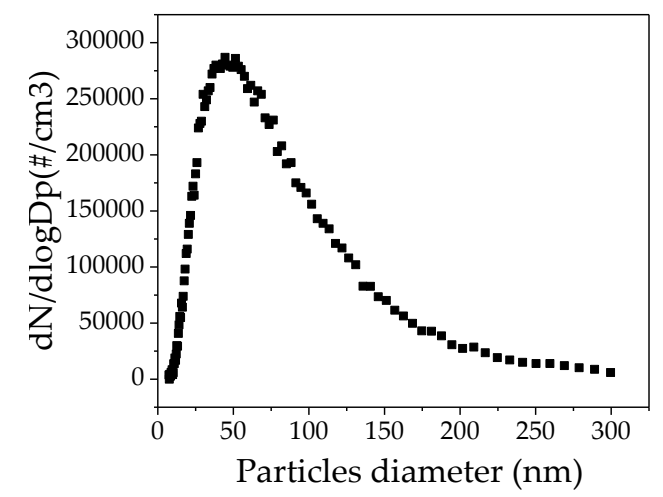

Figure 4. Nanoparticle size distribution using $0.1 \mathrm{~g} / \mathrm{L} \mathrm{NaCl}$ solution.

Then, PAN_F, Ag_F, TiO 2 F, and $\mathrm{ZnO} \_\mathrm{F}$ efficiency in removing these nanoparticles $(9-300 \mathrm{~nm}$ ) from the air stream was measured using a differential mobility analyzer and particle counter and compared to the theoretical efficiency (Figure 5). As expected, the substrate efficiency was very low because it was just a support for the nanofibers and did not influence the filtration efficiency (Figure 5a). Therefore, filtration efficiency was analyzed after exclusion of the substrate, which means a smaller scale (Figure $5 b$ ). The highest filtration efficiency $(\approx 100 \%)$ was observed with $\mathrm{TiO}_{2} \mathrm{~F}$ that also displayed the highest air pressure drop $(\approx 183.47 \mathrm{~Pa})$, due to its higher thickness and formation of particle agglomerates on the nanofibers due to $\mathrm{TiO}_{2}$ nanoparticle size ( $21 \mathrm{~nm}$ in diameter). This performance can be explained by the large specific surface area and low-ordered crystalline structure of $\mathrm{TiO}_{2}$ nanoparticles [58,59]. Zhang et al. [60] demonstrated that $\mathrm{TiO}_{2}$ loading on PAN nanofibers enhances particle removal efficiency due to the high surface-charge that improves the particle's electrostatic attraction. Ag_F also showed high filtration efficiency $(>98 \%)$, but lower pressure drop (68.13 Pa) compared with $\mathrm{TiO}_{2} \mathrm{~F}$, due to the lower Ag_F thickness, resulting from the lower-fiber deposition on the substrate, and probably the lowest average pore size. Moreover, Ag nanoparticles did not agglomerate on the nanofiber, due to their lower size ( $<5 \mathrm{~nm}$ in diameter). $\mathrm{ZnO}$ _F was the least efficient (95\% filtration) among the tested filters, but displayed the lowest pressure drop (81.17 Pa). This could be attributed to the larger pore size and lower thickness compared with $\mathrm{TiO}_{2} \mathrm{~F}$. The higher filtration performance of $\mathrm{Ag}_{-} \mathrm{F}$ despite being less thick than $\mathrm{ZnO}_{-} \mathrm{F}$ could be explained by the smaller pore size of Ag_F, resulting in better removal of airborne particles compared with $\mathrm{ZnO}$ _F. In conclusion, the filter media assessed in this work showed high filtration efficiency, even after nanoparticle loading in the PAN solution.

To understand the different filtration efficiency curve behaviors observed with our filters, the three main capture mechanisms relative to particle size were analyzed: interception, inertial impaction, and diffusion. The filtration curve of our filters is similar to the overall filtration curve for the various filtration mechanisms studied by Hinds (1982) [48], but for $\mathrm{ZnO}$ _F and Ag_F. A small deviation is explained by the fiber and particle diameter, thickness, and porosity, which are normally used to calculate the theoretical efficiency. Generally, particles of $0.1-0.4 \mu \mathrm{m}$ in diameter are considered the most penetrating and can be retained through diffusion and interception filtration. Particles smaller than $0.1 \mu \mathrm{m}$ in diameter are captured through diffusion. Fibrous filters are generally less effective in removing 0.1 to $0.4 \mu \mathrm{m}$ particles. Therefore, particles of 9 to $300 \mathrm{~nm}$ in diameter are too large to be captured by diffusion and too small to be retained by inertial impaction and interception, and so the filter efficiency decreases within this range [61]. 


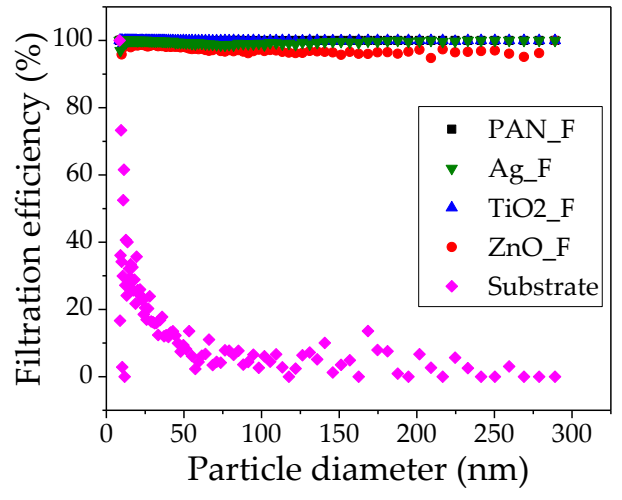

(a)

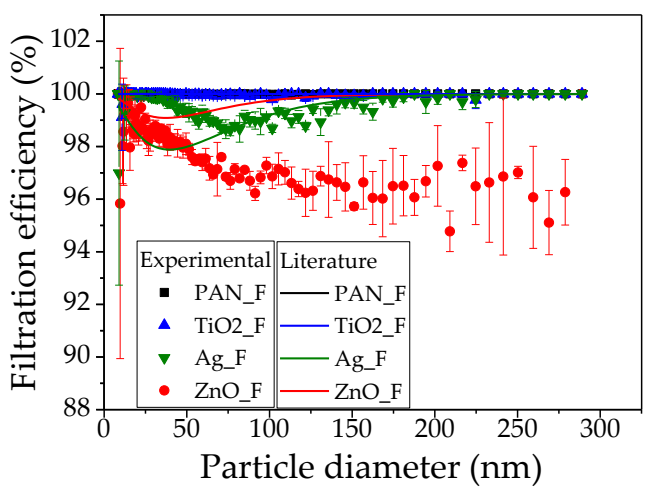

(b)

Figure 5. Experimental and theoretical efficiency of the tested filter media: (a) scale 0-100\% and (b) scale $88-102 \%$.

The performance of filter media can be analyzed using the $Q_{F}$ that was calculated for particles of $100 \mathrm{~nm}$ in diameter (Table 5). High $Q_{F}$ values indicate good filtration efficiency and low pressure drop. In agreement, $\mathrm{Ag} \_\mathrm{F}$ displayed the highest $Q_{F}$ (pressure drop $=68.13 \mathrm{~Pa}$; filtration efficiency: $>98 \%$ ). $\mathrm{TiO}_{2} \_\mathrm{F}$ and $\mathrm{ZnO} \_\mathrm{F}$ had similar $Q_{F}$ values due to the very high pressure drop of $\mathrm{TiO}_{2} \_\mathrm{F}(183.47 \mathrm{~Pa})$, and the low filtration efficiency (>95\%) of ZnO_F. The $Q_{F}$ value of PAN_F $\left(0.05 \mathrm{~Pa}^{-1}\right)$ was good, but this filter does not contain bactericidal nanoparticles. The $Q_{F}$ values of all our filter media, even after addition of $\mathrm{TiO}_{2}, \mathrm{ZnO}$, and $\mathrm{Ag}$ nanoparticles, were comparable to those of previous studies on pristine PAN filters [62-64]. However, superficial velocity, particle size, and material composition might vary among studies and thus data should be compared with caution. Wang et al. [52] demonstrated high filtration efficiency (99.97\%), low pressure drop (57 Pa) and satisfactory $Q_{F}\left(0.14 \mathrm{~Pa}^{-1}\right)$ using 300-500 nm particles. However, the removal of microparticles from air is usually easier compared with nanoparticles. The nanoparticles of 9 to $300 \mathrm{~nm}$ in diameter used in our work are the most difficult to remove and also have been implicated in many diseases [2]. Yet, good $Q_{F}$ values were obtained $\left(\sim 0.05 \mathrm{~Pa}^{-1}\right)$. A relatively small difference was observed because of the slight variation between pressure drop and filtration efficiency for all filters.

Table 5. Quality factor of the different filters.

\begin{tabular}{cc}
\hline Samples & Quality Factor $\left(\mathbf{P a}^{-\mathbf{1}}\right)$ \\
\hline PAN_F & 0.05 \\
$\mathrm{Ag}$ _F & 0.06 \\
$\mathrm{TiO}_{2}$ F & 0.04 \\
ZnO_F & 0.04 \\
\hline
\end{tabular}

On the basis of the European Union Standard for HEPA and ULPA filters-EN 1822 [65], PAN_F filter media could be classified as $\mathrm{H} 13$ (HEPA $>99.95 \%$ collection efficiency), $\mathrm{TiO}_{2} \_\mathrm{F}$ as E12 (Efficiency Particulate Air Filters-EPA >99.5\% collection efficiency), and Ag_F and ZnO_F as E11 (EPA $>95 \%$ collection efficiency). Following the ISO Cleanroom Standards, PAN_F and $\mathrm{TiO}_{2} \mathrm{~F}_{\mathrm{F}}$ can be classified as ISO Class 3, and Ag_F and ZnO_F could be in ISO Class 4 because the limits of the maximum concentration (1000 particles $/ \mathrm{m}^{3}$ of air) for particles of $0.1 \mu \mathrm{m}$ in diameter are exceeded.

\subsection{Bactericidal Activity}

In the direct-contact agar tests using a $10^{8} \mathrm{CFU} / \mathrm{mL}$ E. coli suspension, Ag_F clearly showed the highest bactericidal activity because very few bacterial colonies were visible after plate incubation compared with PAN, ZnO_F, and $\mathrm{TiO}_{2}$ F (Figure 6). Then, the bacterial suspension was decreased to $10^{3} \mathrm{CFU} / \mathrm{mL}$ to try to detect the bactericidal activity of the $\mathrm{ZnO}$ _F and $\mathrm{TiO}_{2} \_\mathrm{F}$ materials (Figure 6) 
and to quantify bacteria removal (Figure 7). For this test, an Ag_F material with lower Ag content $(1 \%$ instead of $50 \% w / w)$ was used to allow bacteria counting. This experiment confirmed the high bactericidal activity of Ag_F (i.e., removal of all bacteria) (Figure 7) whereas $\mathrm{ZnO}_{-} \mathrm{F}$ and $\mathrm{TiO}_{2}$ F did not show any significant antibacterial action. Indeed, the log-removal values were comparable for ZnO_F and $\mathrm{TiO}_{2} \_\mathrm{F}$ and PAN-F, which unexpectedly displayed a $-0.5 \mathrm{log}$ removal. A Student statistical test proved that there is no significant difference among $\mathrm{ZnO}, \mathrm{TiO}_{2}$, and PAN fibers $(p>0.05)$. Some authors $[20,66]$ showed that PAN nanofibers without antibacterial agents do not have bactericidal activity. Conversely, Bortolassi et al. [39] detected a colony decrease with PAN_F ( $25 \pm 12$ CFU, $n=3$ ) compared with control $(87 \pm 10 \mathrm{CFU}, n=3)$, and suggested that bacteria were adsorbed onto PAN material. It can be also hypothesized that when PAN_F (or any other membrane material) is present on the plate surface, a limited $\mathrm{O}_{2}$-mass transfer could slightly reduce the growth of the aerobic bacterium tested. Thus, the PAN_F log-removal value was considered as the baseline value for the tests in our study.

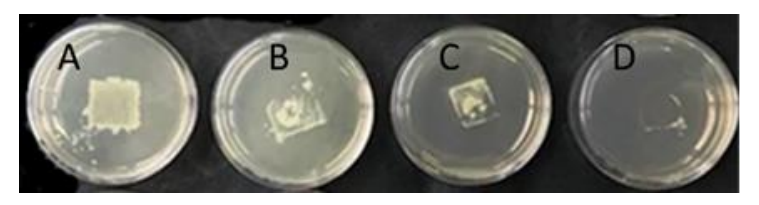

Figure 6. Direct-contact agar tests using $10^{8} \mathrm{CFU} / \mathrm{mL}$ E. coli suspension (contact for $6 \mathrm{~h}$ ): (A) $\mathrm{ZnO} F$; (B) $\mathrm{TiO}_{2} \_\mathrm{F}$; (C) PAN_F; and (D) Ag_F.

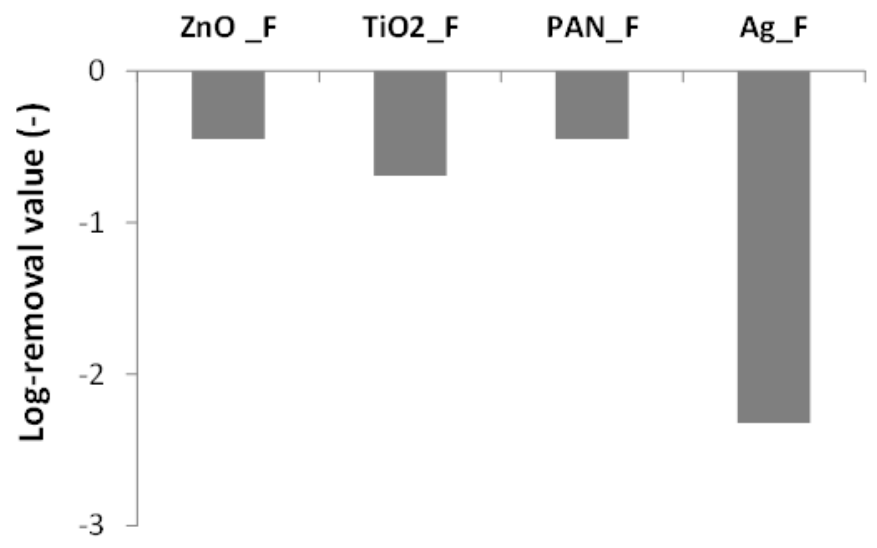

Figure 7. Direct-contact agar tests: log-removal values using a $10^{3} \mathrm{CFU} / \mathrm{mL}$ E. coli suspension that was in contact with the indicated filters for $6 \mathrm{~h}$. The log-removal was calculated as the logarithm (base 10) ratio of the bacterial quantity $\mathrm{Q}(\mathrm{CFU})$ measured after contact with the filter relative to the bacteria quantity $Q_{c}$ in the positive control.

The results obtained with Ag_F are consistent with the literature data. It was previously demonstrated that Ag nanoparticles have high antibacterial effectiveness due to their isotropic geometries, such as spherical particles $[67,68]$ that exhibit large surface-to-volume ratio. Indeed, smaller particles can penetrate more easily in bacteria, especially Gram-negative microorganisms [69]. Some studies reported the antibacterial effect of $\mathrm{ZnO}$ and $\mathrm{TiO}_{2}$ nanoparticles [35,70] without UV illumination [58]. The absence of bactericidal effect of $\mathrm{ZnO}_{-} \mathrm{F}$ and $\mathrm{TiO}_{2} \mathrm{~F}_{\text {in }}$ our work, even when using a $10^{3} \mathrm{CFU} / \mathrm{mL}$ E. coli suspension, could be explained by $\mathrm{ZnO}$ agglomeration and the considerable amount of $\mathrm{TiO}_{2}$ nanoparticles in the nanofibers (Figure 1). Lv et al. [38] observed that by increasing the concentration of $\mathrm{ZnO}$ nanoparticles in PVA and PVA/KGM solutions to more than $1.0 \mathrm{wt} \%$, the solution spinnability was drastically reduced. Moreover, $\mathrm{ZnO}$ particles clustered together and adhered to the fibrous membranes in a random manner. They then showed that the antibacterial activity of a membrane with random $\mathrm{ZnO}$ clusters was lower than that of a membrane with uniformly dispersed $\mathrm{ZnO}$. 
Our results indicate that loading silver nanoparticles in PAN nanofibers using electrospinning is an efficient method to develop air filters for airborne nanoparticle removal with bactericidal activity. They indeed highlight the efficient antibacterial activity, lowest pressure drop (68.13 Pa), high filtration efficiency $(>98 \%)$, highest $Q_{F}\left(0.06 \mathrm{~Pa}^{-1}\right)$, and highest permeability of Ag_F nanofibers, which also displayed the lowest nanofiber deposition during electrospinning.

\section{Conclusions}

In this study, $\mathrm{TiO}_{2} / \mathrm{PAN}, \mathrm{ZnO} / \mathrm{PAN}$, and $\mathrm{Ag} / \mathrm{PAN}$ nanofibers electrospun using the same weight ratio and the same experimental conditions were evaluated. The PAN solution viscosity and conductivity was modified upon addition of the nanoparticles and this affected the nanofiber formation, although they were produced using the same electrospinning parameters. Specifically, viscosity and conductivity were comparable in $\mathrm{TiO}_{2} / \mathrm{PAN} / \mathrm{DMF}$ and $\mathrm{ZnO} / \mathrm{PAN} / \mathrm{DMF}$ solutions, whereas they were much higher for the Ag/PAN/DMF solution ( $933 \mathrm{cP}$ and $2.11 \mathrm{mS} / \mathrm{cm}$, respectively). SEM images confirmed the formation of nanofibers and the homogeneous Ag dispersion on the fibers. On the other hand, $\mathrm{TiO}_{2}$ and $\mathrm{ZnO}$ nanoparticles formed agglomerates on the fibers. Characterization of the filter thickness, pore size, pressure drop, and permeability indicated an overall low pressure drop (from 68.13 to $183.47 \mathrm{~Pa}$ ). The highest filtration efficiency $(\approx 100 \%)$ was obtained with the $\mathrm{TiO}_{2} \mathrm{~F}$ filter, but it also displayed the biggest pressure drop $(\approx 183.47 \mathrm{~Pa})$, probably because of the great number of nanofibers deposited on the substrate. Ag_F showed high filtration efficiency $(>98 \%)$, low pressure drop (68.13 Pa), high $Q_{F}\left(0.06 \mathrm{~Pa}^{-1}\right)$, and very good antibacterial activity against a $10^{8} \mathrm{CFU} / \mathrm{mL}$ E. coli suspension. ZnO_F displayed the lowest filtration efficiency, which was nevertheless $>97 \%$. Therefore, our work shows that filter media maintain high filtration efficiency even after the addition of nanoparticles in the PAN solution. It also suggests that Ag/PAN nanofiber media could be used for many air filtration applications (e.g., masks, cleanrooms, and indoor air purification), thanks also to their bactericidal activity.

Supplementary Materials: The following are available online at http:/www.mdpi.com/2079-4991/9/12/1740/s1, Figure S1: Elemental mapping images of $\mathrm{Ag} / \mathrm{TiO}_{2} / \mathrm{ZnO}-\mathrm{PAN}$ nanofibers (a) $\mathrm{Ag}_{-} \mathrm{F}$; (b) $\mathrm{TiO}_{2} \_\mathrm{F}$; (c) and $\mathrm{ZnO} \_\mathrm{F}$. Table S1: EDX data showing the composition of PAN_F, Ag_F, $\mathrm{TiO}_{2}{ }_{\mathrm{F}} \mathrm{F}$, and $\mathrm{ZnO} \mathrm{Z}_{-} \mathrm{F}$ filters and the substrate.

Author Contributions: Conceptualization, A.C.C.B., V.G.G., and M.B.; methodology, A.C.C.B., V.G.G., M.L.A., L.S., D.C., P.M., and M.B.; formal analysis, A.C.C.B. and V.G.G.; data curation, A.C.C.B., V.G.G., and L.S.; writing-original draft preparation, A.C.C.B.; writing-review and editing, A.C.C.B., V.G.G., M.L.A., L.S., D.C., P.M., and M.B.; supervision, M.L.A., P.M., and M.B.; project administration, M.L.A., P.M., and M.B.; funding acquisition, M.L.A., P.M., and M.B.

Funding: This research was funded by the National Council of Technological and Scientific Development (CNPq), Coordination for the Improvement of Higher Education Personnel (CAPES-Finance Code 001), São Paulo Research Foundation (FAPESP) grant number (2016/20500-6).

Acknowledgments: The authors thank the National Council of Technological and Scientific Development (CNPq), Coordination for the Improvement of Higher Education Personnel (CAPES-Finance Code 001), São Paulo Research Foundation (FAPESP) grant number (2016/20500-6) for their financial support and Freudenberg Group for membranes' supply.

Conflicts of Interest: The authors declare no conflict of interest.

\section{References}

1. D'amato, G. Environmental urban factors (air pollution and allergens) and the rising trends in allergic respiratory diseases. Allergy 2002, 57, 30-33. [CrossRef] [PubMed]

2. Pope, C.A.; Dockery, D.W. Health effects of fine particulate air pollution: Lines that connect. J. Air Waste Manag. Assoc. 2006, 56, 709-742. [CrossRef]

3. Ahuja, K.; Singh, S. Global Industrial Air Filtration Market Size Worth over $\$ 6.5$ bn by 2024. Available online: https://www.gminsights.com/pressrelease/industrial-air-filtration-market (accessed on 26 June 2019).

4. Barhate, R.S.; Ramakrishna, S. Nanofibrous filtering media: Filtration problems and solutions from tiny materials. J. Memb. Sci. 2007, 296, 1-8. [CrossRef] 
5. Mckeen, L.W. Fluorinated Coatings and Finishes Handbook; William Andrew Publishing: Norwich, NY, USA, 2006.

6. Fisk, W.J.; Faulkner, D.; Palonen, J.; Seppanen, O. Performance and costs of particle air filtration technologies. Indoor Air 2002, 12, 223-234. [CrossRef] [PubMed]

7. Givehchi, R.; Tan, Z. The effect of capillary force on airborne nanoparticle filtration. J. Aerosol Sci. 2015, 83, 12-24. [CrossRef]

8. Boskovic, L.; Agranovski, I.E.; Altman, I.S.; Braddock, R.D. Filter efficiency as a function of nanoparticle velocity and shape. J. Aerosol Sci. 2008, 39, 635-644. [CrossRef]

9. Liu, J.; Pui, D.Y.H.; Wang, J. Removal of airborne nanoparticles by membrane coated filters. Sci. Total Environ. 2011, 409, 4868-4874. [CrossRef]

10. Matulevicius, J.; Kliucininkas, L.; Prasauskas, T.; Buivydiene, D.; Martuzevicius, D. The comparative study of aerosol filtration by electrospun polyamide, polyvinyl acetate, polyacrylonitrile and cellulose acetate nanofiber media. J. Aerosol Sci. 2016, 92, 27-37. [CrossRef]

11. Hung, C.H.; Leung, W.W.F. Filtration of nano-aerosol using nanofiber filter under low Peclet number and transitional flow regime. Sep. Purif. Technol. 2011, 79, 34-42. [CrossRef]

12. Al-Attabi, R.; Dumée, L.F.; Kong, L.; Schutz, J.A.; Morsi, Y. High efficiency poly(acrylonitrile) electrospun nanofiber membranes for airborne nanomaterials filtration. Adv. Eng. Mater. 2018, 20, 1700572. [CrossRef]

13. Fan, Z.Y.; Zhao, Y.L.; Zhu, X.Y.; Luo, Y.; Shen, M.W.; Shi, X.Y. Folic acid modified electrospun poly (vinyl alcohol)/polyethyleneimine nanofibers for cancer cell capture applications. Chin. J. Polym. Sci. 2016, 34, 755-765. [CrossRef]

14. Wang, J.; Kim, S.C.; Pui, D.Y.H. Investigation of the figure of merit for filters with a single nanofiber layer on a substrate. J. Aerosol Sci. 2008, 39, 323-334. [CrossRef]

15. Zhang, Q.; Welch, J.; Park, H.; Wu, C.-Y.; Sigmund, W.; Marijnissen, J.C.M. Improvement in nanofiber filtration by multiple thin layers of nanofiber mats. J. Aerosol Sci. 2010, 41, 230-236. [CrossRef]

16. Yun, K.M.; Hogan, C.J.; Matsubayashi, Y.; Kawabe, M.; Iskandar, F.; Okuyama, K. Nanoparticle filtration by electrospun polymer fibers. Chem. Eng. Sci. 2007, 62, 4751-4759. [CrossRef]

17. Ahn, Y.C.; Park, S.K.; Kim, G.T.; Hwang, Y.J.; Lee, C.G.; Shin, H.S.; Lee, J.K. Development of high efficiency nanofilters made of nanofibers. Curr. Appl. Phys. 2005, 6, 1030-1035. [CrossRef]

18. Wang, N.; Si, Y.; Wang, N.; Sun, G.; El-newehy, M.; Al-deyab, S.S.; Ding, B. Multilevel structured polyacrylonitrile/silica nanofibrous membranes for high-performance air filtration. Sep. Purif. Technol. 2014, 126, 44-51. [CrossRef]

19. Vanangamudi, A.; Hamzah, S.; Singh, G. Synthesis of hybrid hydrophobic composite air filtration membranes for antibacterial activity and chemical detoxification with high particulate filtration efficiency (PFE). Chem. Eng. J. 2015, 260, 801-808. [CrossRef]

20. Shalaby, T.; Hamad, H.; Ibrahim, E.; Mahmoud, O.; Al-Oufy, A. Electrospun nanofibers hybrid composites membranes for highly efficient antibacterial activity. Ecotoxicol. Environ. Saf. 2018, 162, 354-364. [CrossRef]

21. Livraghi, S.; Corazzari, I.; Cristina, M.; Ceccone, G.; Giamello, E.; Fubini, B.; Fenoglio, I. Decreasing the oxidative potential of $\mathrm{TiO} 2$ nanoparticles through modification of the surface with carbon: A new strategy for the production of safe UV filters. Chem. Commun. 2010, 46, 8478-8480. [CrossRef]

22. Horie, M.; Iwahashi, H. The impact of the physiochemical properties of manufactured nanoparticles on in vitro and in vivo evaluation of particle toxicity. J. Phys. Chem. Biophys. 2014, 4, 2-5. [CrossRef]

23. Reeves, J.F.; Davies, S.J.; Dodd, N.J.F.; Jha, A.N. Hydroxyl radicals (.OH) are associated with titanium dioxide (TiO2) nanoparticle-induced cytotoxicity and oxidative DNA damage in fish cells. Mutat. Res. 2008, 640, 113-122. [CrossRef] [PubMed]

24. Ivask, A.; Bondarenko, O.; Jepihhina, N.; Kahru, A. Profiling of the reactive oxygen species-related ecotoxicity of $\mathrm{CuO}, \mathrm{ZnO}, \mathrm{TiO}_{2}$, silver and fullerene nanoparticles using a set of recombinant luminescent Escherichia coli strains: Differentiating the impact of particles and solubilised metals. Anal. Bioanal. Chem. 2010, 398, 701-716. [CrossRef] [PubMed]

25. Zhang, L.; Jiang, Y.; Ding, Y.; Povey, M.; York, D. Investigation into the antibacterial behaviour of suspensions of $\mathrm{ZnO}$ nanoparticles (ZnO nanofluids). J. Nanopart. Res. 2007, 9, 479-489. [CrossRef]

26. Lu, S.; Yu, J.; Cheng, Y.; Wang, Q.; Barras, A.; Xu, W.; Szunerits, S.; Cornu, D.; Boukherroub, R. Preparation of silver nanoparticles/polydopamine functionalized polyacrylonitrile fiber paper and its catalytic activity for the reduction 4-nitrophenol. Appl. Surf. Sci. 2017, 411, 163-169. [CrossRef] 
27. Park, H.; Yeon, J.; Kim, J.; Lee, J.; Hahn, J.; Bock, M.; Yoon, J. Silver-ion-mediated reactive oxygen species generation affecting bactericidal activity. Water Res. 2009, 43, 1027-1032. [CrossRef]

28. De Faria, A.F.; Martinez, D.S.; Meira, S.M.; de Moraes, A.C.; Brandelli, A.; Souza Filho, A.G.; Alves, O.L. Anti-adhesion and antibacterial activity of silver nanoparticles supported on graphene oxide sheets. Colloids Surf. B Biointerfaces 2014, 113, 115-124. [CrossRef]

29. Wu, Q.; Wan, L.; Xu, Z. Structure and performance of polyacrylonitrile membranes prepared via thermally induced phase separation. J. Memb. Sci. 2012, 409-410, 355-364. [CrossRef]

30. Pokhum, C.; Intasanta, V.; Yaipimai, W.; Subjalearndee, N.; Srisitthiratkul, C.; Pongsorrarith, V.; Phanomkate, N.; Chawengkijwanich, C. A facile and cost-effective method for removal of indoor airborne psychrotrophic bacterial and fungal flora based on silver and zinc oxide nanoparticles decorated on fibrous air filter. Atmos. Pollut. Res. 2018, 9, 172-177. [CrossRef]

31. Feng, S.; Li, D.; Low, Z.X.; Liu, Z.; Zhong, Z.; Hu, Y.; Wang, Y.; Xing, W. ALD-seeded hydrothermally-grown $\mathrm{Ag} / \mathrm{ZnO}$ nanorod PTFE membrane as efficient indoor air filter. J. Memb. Sci. 2017, 531, 86-93. [CrossRef]

32. Decelis, S.; Sardella, D.; Triganza, T.; Brincat, J.P.; Gatt, R.; Valdramidis, V.P. Assessing the anti-fungal efficiency of filters coated with zinc oxide nanoparticles. R. Soc. Open Sci. 2017, 4, 1-9. [CrossRef]

33. Lv, D.; Zhu, M.; Jiang, Z.; Jiang, S.; Zhang, Q.; Xiong, R. Green electrospun nanofibers and their application in air filtration. Macromol. Mater. Eng. 2018, 303, 1800336. [CrossRef]

34. Lala, N.L.; Ramaseshan, R.; Bojun, L.; Sundarrajan, S.; Barhate, R.S.; Ying-jun, L.; Ramakrishma, S. Fabrication of nanofibers with antimicrobial functionality used as filters: Protection against bacterial contaminants. Biotechnol. Bioeng. 2007, 97, 1357-1365. [CrossRef] [PubMed]

35. Hwang, S.H.; Song, J.; Jung, Y.; Kweon, O.Y.; Song, H.; Jang, J. Electrospun ZnO/TiO2 composite nanofibers as a bactericidal agent. Chem. Commun. 2011, 47, 9164-9166. [CrossRef] [PubMed]

36. Shalaby, T.; Mahmoud, O.; Al-Oufy, A. Antibacterial silver embedded nanofibers for water disinfection. Int. J. Mater. Sci. Appl. 2015, 4, 293-298. [CrossRef]

37. Sim, M.K.; Park, H.; Bae, G.; Jung, H.J. Antimicrobial nanoparticle-coated electrostatic air filter with high filtration efficiency and low pressure drop. Sci. Total Environ. 2015, 533, 266-274. [CrossRef]

38. Lv, D.; Wang, R.; Tang, G.; Mou, Z.; Lei, J.; Han, J.; Smedt, S.; Xiong, R.; Huang, C. Ecofriendly electrospun membranes loaded with visible-light-responding nanoparticles for multifunctional usages: Highly efficient air filtration, dye scavenging, and bactericidal activity. ACS Appl. Mater. Interfaces 2019, 11, 12880-12889. [CrossRef]

39. Bortolassi, A.C.C.; Nagarajan, S.; de Araújo Lima, B.; Guerra, V.G.; Aguiar, M.L.; Huon, V.; Soussan, L.; Cornu, D.; Miele, P.; Bechelany, M. Efficient nanoparticles removal and bactericidal action of electrospun nanofibers membranes for air filtration. Mater. Sci. Eng. C 2019, 102, 718-729. [CrossRef]

40. Lee, H.K.; Jeong, E.H.; Baek, C.K.; Youk, J.H. One-step preparation of ultrafine poly(acrylonitrile) fibers containing silver nanoparticles. Mater. Lett. 2005, 59, 2977-2980. [CrossRef]

41. Navaladian, S.; Viswanathan, B.; Viswanath, R.; Varadarajan, T. Thermal decomposition as route for silver nanoparticles. Nanoscale Res. Lett. 2007, 2, 44-48. [CrossRef]

42. Santos, I.P.; Rodríguez, C.S.; Marzán, L.M.L. Self-Assembly of Silver Particle Monolayers on Glass from Ag ${ }^{+}$ Solutions in DMF. J. Colloid Interdace Sci. 2000, 221, 236-241. [CrossRef]

43. Nars, M.; Balme, S.; Eid, C.; Habchi, R.; Miele, P.; Bechelany, M. Enhanced Visible-Light Photocatalytic Performance of Electrospun $\mathrm{rGO} / \mathrm{TiO}_{2}$ Composite Nanofibers. J. Phys. Chem. C 2017, 121, 261-269.

44. Nada, A.A.; Bekheet, M.F.; Viter, R.; Miele, F.; Roualdes, S.; Bechelany, M. BN/GdxTi(1-x)O(4-x)/2 nanofibers for enhanced photocatalytic hydrogen production under visible light. Appl. Catal. B Environ. 2019, 251, 76-86. [CrossRef]

45. Bechelany, M.; Drobek, M.; Vallicari, C.; Abou Chaaya, A.; Julbe, A.; Miele, P. Highly Crystalline MOF-based Materials Grown on Electrospun Nanofibers. Nanoscale 2015, 7, 5794-5802. [CrossRef] [PubMed]

46. Bortolassi, A.C.C.; Guerra, V.G.; Aguiar, M.L. Characterization and evaluate the efficiency of different filter media in removing nanoparticles. Sep. Purif. Technol. 2016, 175, 79-86. [CrossRef]

47. Dumee, L.; Sears, K.; Schutz, J.; Finn, N.; Duke, M.; Gray, S. Influence of the sonication temperature on the debundling kinetics of carbon nanotubes in propan-2-ol. Nanomaterials 2013, 3, 70-85. [CrossRef] [PubMed]

48. Hinds, W.C. Aerosol Technology Properties, Behavior and Measure of Airborne Particles, 2nd ed.; Sons, J.W., Ed.; John Wiley \& Sons, Inc.: New York, NY, USA, 1982. 
49. Nicosia, A.; Keppler, T.; Müller, F.A.; Vazquez, B.; Ravegnani, F.; Monticelli, P. Cellulose acetate nanofiber electrospun on nylon substrate as novel composite matrix for efficient, heat-resistant, air filters. Chem. Eng. Sci. 2016, 153, 284-294. [CrossRef]

50. Li, Z.; Wang, C. Effects of working parameters on electrospinning. In One-Dimensonal Nanostructures; Springer: Berlin/Heidelberg, Germany, 2013; pp. 15-28, ISBN 9783642364273.

51. Yar, A.; Haspulat, B.; Üstün, T.; Eskizeybek, V.; Avci, A.; Kamiş, H.; Achour, S. Electrospun TiO2/ZnO/PAN hybrid nanofiber membranes with efficient photocatalytic activity. RSC Adv. 2017, 7, 29806-29814. [CrossRef]

52. Wang, Z.; Pan, Z.; Wang, J.; Zhao, R. A novel hierarchical structured poly(lactic acid)/titania fibrous membrane with excellent antibacterial activity and air filtration performance. J. Nanomater. 2016, 2016, 39. [CrossRef]

53. Abdo, H.S.; Khalil, K.A.; Al-deyab, S.S.; Altaleb, H.; Sherif, E.M. Antibacterial Effect of Carbon Nanofibers Containing Ag Nanoparticles. Fibers Polym. 2013, 14, 1985-1992. [CrossRef]

54. Li, G.; Zhao, Y.; Lv, M.; Shi, Y.; Cao, D. Super hydrophilic poly (ethylene terephthalate) (PET)/poly(vinyl alcohol) (PVA) composite fibrous mats with improved mechanical properties prepared via electrospinning process. Colloids Surfaces A Physicochem. Eng. Asp. 2013, 436, 417-424. [CrossRef]

55. Haider, S.; Al-zeghayer, Y.; Ali, F.A.A.; Imran, M.; Aijaz, M.O. Highly aligned narrow diameter chitosan electrospun nanofibers. J. Polym. Res. 2013, 20, 105. [CrossRef]

56. Barhate, R.S.; Loong, C.K.; Ramakrishna, S. Preparation and characterization of nanofibrous filtering media. J. Memb. Sci. 2006, 283, 209-218. [CrossRef]

57. Zhang, P.; Shao, C.; Zhang, Z.; Zhang, M.; Mu, J.; Guo, Z.; Liu, Y. In situ assembly of well-dispersed Ag nanoparticles (AgNPs) on electrospun carbon nanofibers (CNFs) for catalytic reduction of 4-nitrophenol. Nanoscale 2011, 3, 3357. [CrossRef] [PubMed]

58. Lee, W.S.; Park, Y.S.; Cho, Y.K. Significantly enhanced antibacterial activity of $\mathrm{TiO}_{2}$ nanofibers with hierarchical nanostructures and controlled crystallinity. Analyst 2015, 140, 616-622. [CrossRef]

59. Chen, X.; Mao, S.S. Titanium dioxide nanomaterials: Synthesis, properties, modifications, and applications. Chem. Rev. 2007, 107, 2891-2959. [CrossRef]

60. Zhang, Q.; Liu, F.; Yang, T.-Y.; Si, X.L.; Hu, G.R.; Chang, C.-T. Deciphering effects of surface charge on particle removal by TiO2 polyacrylonitrile nanofibers. Aerosol Air Qual. Res. 2017, 17, 1909-1916. [CrossRef]

61. Mechanisms of Filtration for High Efficiency Fibrous Filters Application Note ITI-041. TSI Instruments. 2012. Available online: www.tsi.com/getmedia/4982cf03-ea99-4d0f-a660-42b24aedba14/ITI-041-A4?.ext=.pdf (accessed on 04 December 2019).

62. Al-Attabi, R.; Morsi, Y.; Kujawski, W.; Kong, L.; Schütz, J.; Dumée, L.F. Wrinkled silica doped electrospun nano-fiber membranes with engineered roughness for advanced aerosol air filtration. Sep. Purif. Technol. 2019, 215, 500-507. [CrossRef]

63. Al-Attabi, R.; Dumée, L.F.; Schutz, J.A.; Morsi, Y. Pore engineering towards highly efficient electrospun nanofibrous membranes for aerosol particle removal. Sci. Total Environ. 2017, 625, 706-715. [CrossRef]

64. Podgorski, A.; Balazy, A.; Gradon, L. Application of nanofibers to improve the filtration efficiency of the most penetrating aerosol particles in fibrous filters. Chem. Eng. Sci. 2006, 61, 6804-6815. [CrossRef]

65. European Committee for Standardization. European Standard EN 1822 High Efficiency Air Filters (EPA, HEPA and ULPA); CEN: Brussels, Belgium, 2009.

66. Mahapatra, A.; Garg, N.; Nayak, B.P.; Mishra, B.G.; Hota, G. Studies on the synthesis of electrospun PAN-Ag composite nanofibers for antibacterial application. J. Appl. Polym. Sci. 2012, 124, 1178-1185. [CrossRef]

67. Albanese, A.; Tang, P.S.; Chan, W.C.W. The effect of nanoparticle size, shape, and surface chemistry on biological systems. Annu. Rev. Biomed. Eng. 2012, 14, 1-16. [CrossRef] [PubMed]

68. Agnihotri, S.; Mukherji, S.; Mukherji, S. Size-controlled silver nanoparticles synthesized over the range 5-100 nm using the same protocol and their antibacterial efficacy. RSC Adv. 2014, 4, 3974-3983. [CrossRef]

69. Morones, J.R.; Elechiguerra, J.L.; Camacho, A.; Holt, K.; Kouri, J.B.; Ramírez, J.T.; Yacaman, M.J. The bactericidal effect of silver nanoparticles. Nanotechnology 2005, 16, 2346-2353. [CrossRef] [PubMed]

70. Liu, Y.; He, L.; Mustapha, A.; Li, H.; Hu, Z.Q.; Lin, M. Antibacterial activities of zinc oxide nanoparticles against Escherichia coli O157:H7. J. Appl. Microbiol. 2009, 107, 1193-1201. [CrossRef]

(C) 2019 by the authors. Licensee MDPI, Basel, Switzerland. This article is an open access article distributed under the terms and conditions of the Creative Commons Attribution (CC BY) license (http://creativecommons.org/licenses/by/4.0/). 